\title{
Acoustic Behavior in Three Types of Housing: Brick Social Housing, Structural Insulated Panel (SIP) Emergency Housing and Mediagua Emergency Housing
}

\author{
Proyecto Vivienda de Emergencia, Parte 3, Comportamiento acústico
}

Rose Marie Garay (Main and Corresponding Author)

Departamento de Ingeniería de la Madera y Biomateriales, Facultad de Ciencias Forestales y Conservación de la Naturaleza, Universidad de Chile; Programa de Reducción de Riesgo de Desastre (CITRID)

Postal Code 9206, Santiago (Chile)

rgaray@uchile.cl

\section{Nidia Pino G.}

Departamento de Ingeniería de la Madera y Biomateriales, Facultad de Ciencias Forestales y Conservación de la Naturaleza, Universidad de Chile

Postal Code 9206, Santiago (Chile)

nidi_ita@hotmail.com

Manuscript Code: 1099

Date of Acceptance/Reception: 08.04.2019/11.04.2018

DOI: $10.7764 /$ RDLC.18.1.96

\begin{abstract}
As part of the analysis of the technical criteria for emergency housing of Fondef project D09I1058, the acoustic behavior of three types of dwellings was measured: brick social housing, structural insulated panel (SIP) emergency housing and "mediagua" emergency housing. The acoustic reduction index (Rw) was measured in medium-density fiberboard (MDF), oriented strand board (OSB), plywood (Plywood), hard fiberboard (HB) and particle board (PB). PB and HB obtained Rw values of $20 \mathrm{~dB}$, while MDF and Plywood obtained Rw values of $17 \mathrm{~dB}$, and OSB obtained an Rw value of $19 \mathrm{~dB}$, reflecting an additional positive characteristic of their structural properties that enables a lower cost for the manufacture of SIP emergency housing in compliance with the technical thermal mechanical regulations enforced by the General Ordinance of Urbanism and Construction (Ordenanza General de Urbanismo y Construcción, OGUC). To reduce costs, these dwellings were not designed to comply with acoustic regulations, but if they were evaluated for compliance, their result would fulfill the important criteria for a positive impact on acoustic insulation. NCh 432-10, according to OGUC, requires a minimum attenuation of $45 \mathrm{~dB}$ (Insttituto Nacional de Normalización, 2010a) in paired walls for social housing but not for emergency housing. The test was performed according to NCh 2785-2002 (Instituto Nacional de Normalizacion, 2002), using a sound-emitting speaker and a sound level meter, to obtain the attenuation of the paired wall. The social housing reached an attenuation of $42 \mathrm{~dB}$, the SIP housing reached an attenuation of $39 \mathrm{~dB}$, and the mediagua housing reached an attenuation of $6 \mathrm{~dB}$, evidencing the precariousness of housing that is constructed from low-quality wood and that is poorly assembled, without air- and water-tightness, consequently affecting quality of life.
\end{abstract}

Keywords: shelter, habitability, wood acoustic properties, noise regulations, houses, acoustic insulation.

Resumen

Como parte del análisis de criterios técnicos en viviendas de emergencia del proyecto Fondef D09I1058, se midió el comportamiento acústico en tres viviendas: social en ladrillo, de emergencia en Structural Insulated Panel (SIP) y de emergencia en "mediagua". Se midió el índice de reducción acústica (Rw) en tableros de fibra de densidad media (MDF), hojuelas orientadas (OSB), contrachapados (Plywood), fibra duros (HB) y partículas (PB). PB y HB obtuvieron el Rw más alto (20 dB), MDF y Plywood Rw más bajos (17 dB). En OSB, Rw fue 19 dB, característica positiva adicional a sus propiedades estructurales y menor costo para fabricar SIP en vivienda de emergencia bajo criterios técnicos, reglamentación térmica, fuego y mecánica vigentes de la Ordenanza General de Urbanismo y Construcción (OGUC). Estas viviendas, no fueron diseñadas para cumplir la reglamentación acústica para no aumentar sus costos, si fueron evaluadas para este criterio, correspondiendo su resultado al cumplimiento de los criterios prioritarios, que impactaron positivamente en la aislación acústica. OGUC establece obligatoriedad de la Norma NCH 432-10 (Instituto Nacional de Normalización, 2010b) para vivienda social, no para vivienda de emergencia, exigiendo una atenuación mínima de 45 dB en muros pareados. El ensayo se realizó según NCh 27852002 (Instituto Nacional de Normalización, 2002), mediante un parlante emisor y un sonómetro, obteniéndose la atenuación del muro pareado. La vivienda social alcanzó 42 dB, la vivienda en SIP 39 dB, la mediagua 6 dB, evidenciando la precariedad al fabricarlas con madera de baja calidad y mal ensambladas, sin hermeticidad al agua y al aire, afectando la calidad de vida.

Wood as a construction material is lightweight, durable and environmentally friendly. Its composition of cellulose fibers, lignin, hemicellulose and extractables allows it to be resistant and ductile, supporting extreme forces and nonpermanent deformations. Wood contributes to thermal insulation via its low thermal transmittance, helping to reduce thermal bridges (which are more complex in concrete and steel). However, wood has properties that require supplementation, particularly fire resistance, acoustic behavior, and thermal inertia or the ability to serve as a heat storage mass to prevent a rapid heating or cooling effect (Saleh Pascha, 2013). 
The acoustic requirements of aerial noise and impact are established in minimum standards of habitability for social housing (which does not include emergency housing). According to (Ministerio de la Vivienda y Urbanismo, 2017), vertical and horizontal construction elements must attenuate aerial noise by $45 \mathrm{dBA}$, and the impact noise that is transmitted in horizontal elements must be at most $75 \mathrm{~dB}$ (Ministerio de Vivienda y Urbanismo, 2014).

In acoustic architecture, the properties of materials are utilized to create buildings with satisfactory acoustics, characterized by the control of the transmission of sound through the construction elements, absorption of sound inside the enclosure and transmission of noise between rooms. Wood and boards are materials with superior acoustic properties due to their ability to absorb incident sound, reducing the sound pressure level or reverberation time in the room; they are usually incorporated into walls, ceilings and floors and/or suspended in space, according to the application requirements (theaters, offices, industrial buildings, homes, etc.). Acoustic design selects materials to absorb, reflect or transmit incident waves; how well this is achieved will depend on the designer's knowledge and ability to use and select materials (Bucur, 1996). The efficiency of the absorption and reflection of sound in the audible spectrum is related to the internal structure of the material, surface treatment, type of assembly and geometry. For example, plywood (Plywood) and particle board (PB) absorb low frequencies of the spectrum $(<500 \mathrm{~Hz})$, whereas more porous materials can absorb middle and high frequencies $(2000-4000 \mathrm{~Hz})$.

These analyses are common in acoustic architecture but are not commonly applied in homes. When there is a more strict acoustic requirement, simulation software (Easy, Soundplan, Insul, Minerva or Sonarchitect) is used to analyze the materials chosen, considering terrestrial and aerial noise transport, high concurrency, etc. This allows the verification of compliance.

In an investigation by (Fundación Chile, 2004) in residential buildings built from concrete and brick, the most common exterior and interior sources of noise were analyzed. It was concluded that these houses do not comply with the noise regulations for buildings, noting that there are acoustic differences between apartments within the same building.

Acoustic standards in buildings are a subject of increasing development (Bustos, 2011) due to the growth and activity of cities, which are increasingly noisy places. In Chile, since 2000, following the enactment of the norm (Instituto Nacional de Normalización, 2000), social housing must meet acoustic comfort requirements for comfortable habitability (Ministerio de Vivienda y Urbanismo, 2014). Most are built with perimeter walls of brick and interior walls of wood and with plasterboard and zinc on wood trusses in the roof structure (Ministerio del Medio Ambiente, 2012) establishes maximum permitted noise emission levels (Table 1), identifying defined zones in territorial planning, with zone I corresponding to territories with residential homes.

Table 1. Maximum sound pressure levels (NPS) allowed (Decree 38) (DBA). Source: Article 7. Supreme Decree No. 38/11 of the Environment Ministry.

\begin{tabular}{|c|c|c|}
\hline Timetables $(\mathrm{Hr}) 1: 7$ to $21,2: 21$ to 7 & 1 & 2 \\
\hline I: Allows use of only residential land, includes public space and/or green area & 55 & 45 \\
\hline II: Allows zone I uses and equipment of any scale & 60 & 45 \\
\hline III: Allows zone II uses and productive activities and/or infrastructure & 65 & 50 \\
\hline IV: Allows land uses in only productive activities and/or infrastructure & 70 & 70 \\
\hline
\end{tabular}

The acoustic requirements for dividing elements between independent housing units, aimed at minimizing the traumatic effects of aerial noise and impacts to buildings with more than 1 constructed floor, are shown in Figure 1 (Ministerio de la Vivienda y Urbanismo, 2006).

Figure 1. Acoustic requirements dividing elements between housing units (Ministerio de la Vivienda y Urbanismo, 2006).

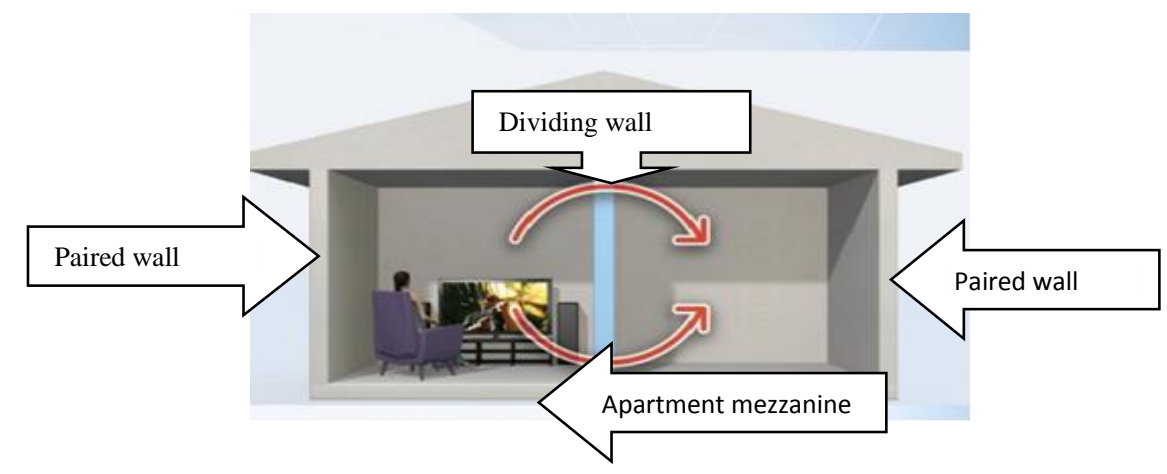


Emergency housing is minimal and temporary. It is built with 1 or more floors to solve the basic conditions of subsistence and shelter for people affected by emergencies resulting from disasters due to natural, social or accident phenomena, and its characteristics, requirements and provisions must be specified and regulated. Because of its transitory nature, this type of housing is exempt from compliance with the legal provisions or regulations required for permanent social housing (Ministerio de la Vivienda y Urbanismo, 2017; Ministerio de Vivienda y Urbanismo, 2014). The temporary dwelling called "mediagua" is made with wood partitions and zinc plates, and its regulation is weak and incomplete. In the last 5 years, structural insulated panels (SIPS) have begun to be incorporated to improve housing, although only some technical aspects of these materials and surfaces have been addressed. The SIP houses delivered by ONEMI in recent years are of higher quality; some standard specifications include additional sealing, an interior lining and built-in bathrooms (Garay, PFenniger, Tapia \& Larenas, 2014). However, emergency dwellings do not meet thermal comfort, fire, seismic or acoustic comfort standards. Through Fondef project D09I1058 (Garay et al., 2014), emergency housing prototypes were designed and built using SIPs but manufactured to comply with structural, fire resistance, airtightness, durability and thermal standards. Acoustic insulation was not considered a priority, although the quality of life and mental health of the victims would be affected. Elucidating the actual acoustic insulation properties would allow a search for alternatives to improve it.

Garay \& Silva (2011) characterized the acoustic behavior of several boards, following the methodologies of Instituto Nacional de Normalización, (2000), and concluded that the heterogeneity in the internal structure of the boards explains the ultrasonic attenuation, with better acoustic construction solutions from less homogeneous and denser boards, which produce a greater obstacle to the passage of sound.

It is necessary to understand that sound is a vibration in a medium: a result of the alternation of pressures and movements of particles in its interior. Therefore, the elastic media considered in architecture are gas (air), liquids (fluids) and solids (building materials and earth). When molecules in an elastic medium move back and forth in opposite directions, they form a cycle. The molecules within the medium only vibrate, but the sound of the vibration moves quickly and travels far (APA, 2017; Bucur, 1996; Peraza, 2002). Wood has the capacity to dampen sound vibrations. Its porous cellular structure transforms sound energy into heat due to the friction and viscous resistance of the medium, thus preventing the transmission of vibrations over great distances (APA, 2017).

Sound insulation depends on not only the building materials but also the building type. By managing the concepts of reflection, absorption and transmission, acoustic solutions are designed. Noise passes from one environment to another via different paths (Figure 2), not only the dividing elements between 2 spaces but also the joints, sidewalls, ceiling and floor. Uprights and transversal beams transmit noise because they are rigid joints. Sound waves are affected only when there is a considerable change in material, for example, air to wood, creating an acoustic bridge and allowing noise to pass from one room to another. As there is no change in material that dampens the noise, the air spaces inside the partition absorb some of the noise, decreasing its passage to the adjoining room.

Figure 2. Sound through the partition Source: APA (2017) a) in the union and b) between right feet.

a)

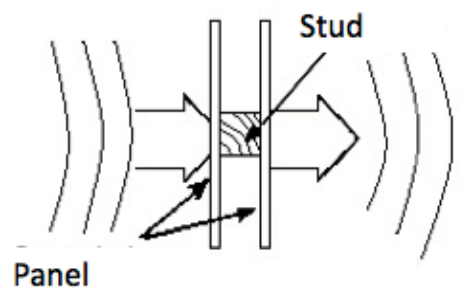

b)

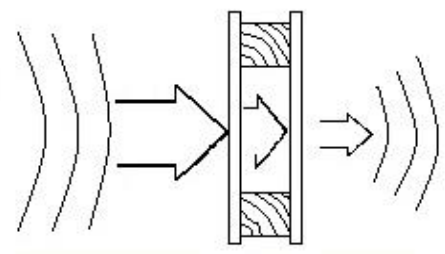

Figure 3. a) Half-timbered partition. Source: APA (2017) b) Multiple partition.

a)

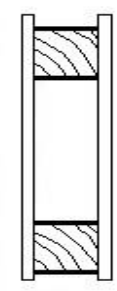

b)

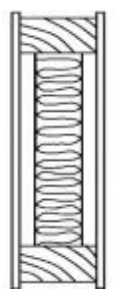

A multiple partition is constructed of layers that enclose air spaces, acting as a damper; the smaller the air space is, the lower the damping and the more intense the sound transmission. The damping of sound propagated by the air increases with the weight of the partition per $\mathrm{m}^{2}$ and with the thickness of the layer of air between the partial walls.

Sound-transmitting bridges (fixed joints) must be avoided by using tubular pipes or mortars. A half-timbered partition acts as a double wall; because of the rigid cladding, the total frame vibrates at the same time as the partial surfaces, so they have a damping effect slightly larger than that of a single partition of the same weight. Figure 4 shows a double partition, with wooden slats, with a greater acoustic damping than would correspond to its weight. Such partitions can be manufactured quickly and simply and are suitable as room dividers or acoustic booths in noisy environments. 
A SIP comprises 2 9.4-mm oriented strand boards (OSBs) plus an expanded polystyrene (EPS) center with a thickness and a density designed according to the thermal zone requirements, bonded with bicomponent polyurethane. SIPs can be used in roof structures, walls and floors. SIP dimensions are $1.22 \mathrm{~m} \times 2.44 \mathrm{~m}$, and it has a weight of 48 to $50 \mathrm{~kg}$ and a thermal resistance of $2.23 \mathrm{~m}^{2} \mathrm{~K} / \mathrm{W}$ (Instituto Nacional de Normalización, 2016).

The presence of acoustic bridges usually coincides with that of thermal bridges, so the materials should ideally satisfy both functions simultaneously. Sound is caused by not only the collision of 2 bodies but also the conversion of the sound transmitted by the air when it is vibrating some part of the construction. In simple partitions, without intermediate air spaces, the sound transmission occurs via flexion vibrations, making it necessary to arrange the wall in such a way that produces the greatest possible resistance to the sound pressure, making the partition as heavy and rigid as possible. According to the German standard for simple air-impermeable partitions corresponding to $450 \mathrm{~kg} / \mathrm{m}^{2}$, a minimum average damping of $53 \mathrm{~dB}$ is required for frequencies between 100 and $3000 \mathrm{~Hz}$. Figure 4 shows the damping, under the same frequency, of a brick and stone $1 / 1$ partition and 5-mm thick Plywood; the Plywood has a weight of $2 \mathrm{~kg} / \mathrm{m}^{2}$ and an average sound damping of $19 \mathrm{~dB}$.

Figure 4. Brick partition vs. wood partition. Source: Kollmann (1959).

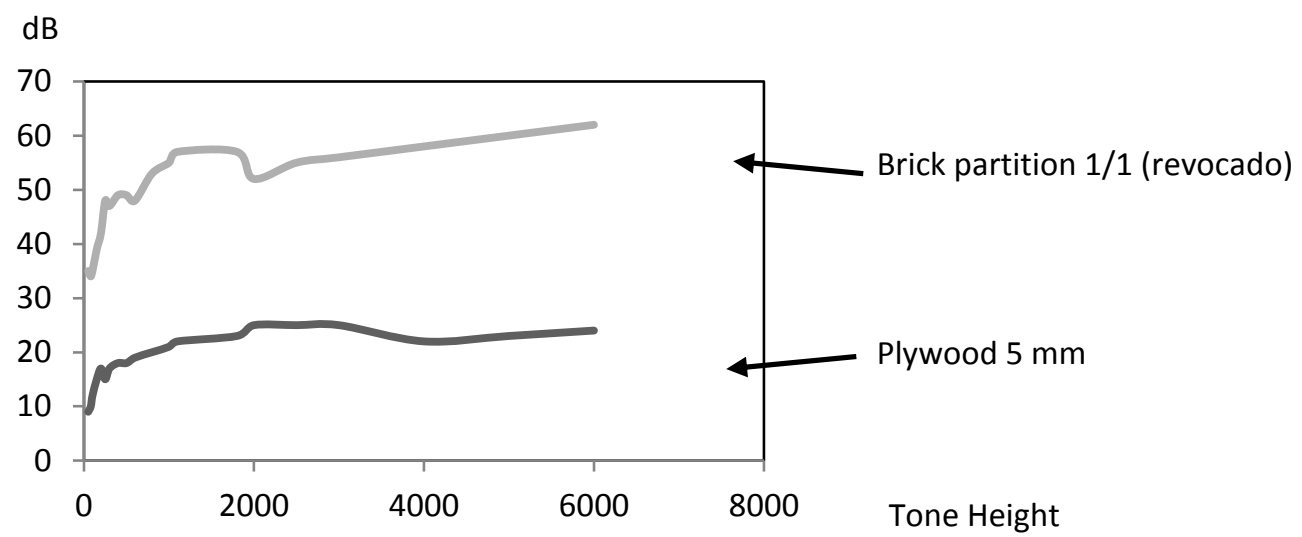

Air-borne sound can be dampened, albeit weakly, by simple wooden constructions (for example, by wood frames covered partially with boards or fiberboards), as these constructions are very light and have a great capacity for vibration. Tufted partitions, covered on both sides with wood or fiberboards, cushion between 37 and $44 \mathrm{~dB}$ at weights of 50 to $100 \mathrm{~kg} / \mathrm{m}^{2}$ (Kollmann, 1959) and are affected by parts more permeable to sound (doors, windows and air access). Loss of sound transmission increases with the irregularity and frequency of sound; there is a characteristic limiting frequency at which an extraordinary reduction in the acoustic insulation occurs, determined by the quotient of the dynamic modulus of elasticity of the material in the form of a shell. For acoustic insulation, it is necessary that the frequency range scale be 100 to $3000 \mathrm{~Hz}$. Double walls (multishell) can provide efficient acoustic insulation. The problem of sound absorption is different from that of acoustic insulation, as acoustic absorption requires soft porous materials, such as carpets, heavy fabrics, wood wool and acoustic tiles, whereas denser materials are used for acoustic insulation. Plywood has a maximum sound absorption of approximately $26 \%$ at a frequency of $512 \mathrm{~Hz}$, and above $1000 \mathrm{~Hz}$, the sound absorption is approximately constant (10\%). At a 20-mm thickness (frequencies from 100 to $5000 \mathrm{~Hz}$ ), it has sound absorption between 8 and $11 \%$. This knowledge is used where acoustic architecture is relevant; curved walls are built in the form of shells with materials that have reflective properties to facilitate the passage of sound to audiences.

The construction elements of wood do not have great acoustic insulation if their densities are low. For example, a 35$\mathrm{mm}$ thick, slightly dense coniferous wood door weighing $21 \mathrm{~kg} / \mathrm{m}^{2}$ has an acoustic reduction index (Rw) of $14 \mathrm{dBA}$, while an oak door of the same thickness, weighing $28 \mathrm{~kg} / \mathrm{m}^{2}$, has an Rw of $16 \mathrm{dBA}$ (Kollmann, 1975).

In construction elements made of several sheets, the acoustic insulation does not follow the mass law, as there is a loss of energy via the dissipation of heat through the system. An element formed by 2 sheets between which there is an elastic and porous material, for example, glass wool or coconut fibers (Zulkifli, Mohd, Tahir, Ismail \& Nuawi, 2008), has an acoustic behavior that responds to the mass-spring-mass principle. The fibrous structure (porous) absorbs part of the mechanical energy transported by the waves, transforming it into heat via friction. Therefore, within a certain limit, the more rigid this material is, the worse the insulation (the worse the efficiency of the mass-spring-mass system). Thus, a wall of 2 15-mm gypsum plasterboards and a 50-mm glass wool interior provides an acoustic insulation of Rw $39 \mathrm{dBA}$, a concrete wall 11-cm thick provides an acoustic insulation of $38 \mathrm{dBA}$, and a 1/2-foot double hollow brick wall 14-cm thick provides an Rw of $38 \mathrm{dBA}$. When there is also a fire resistance requirement, i.e., when the compatibility of criteria 
is required, density should be increased at the sides of the composite wall and not in the center to fulfill the acoustic and thermal functions.

The acoustic insulation to noise produced by floor impacts, which is the most frequent case, is improved with floating coatings on elastic supports. These elements can be floating floors or false ceilings. The reduction in the impact noise level by multilayer parquet installed on an elastic layer is $20 \mathrm{dBA}$.

Wood fulfills structural, functional and decorative functions. Sometimes it is purely decorative, with the structural function being provided by other materials; in other cases, it provides the functionalities of thermal, acoustic and fire insulation. Most often, wood fulfills simultaneous functions, e.g., in wooden houses (Garay, Poblete \& Karsulovic, 2009; Garay \& Henriquez, 2010; Garay, Figueroa, Pfenniger, Tapia \& Larenas, 2017)

This study provides information on the acoustic reduction index of boards and evaluates the acoustic behavior of 3 types of dwellings: SIP emergency housing, social housing and mediagua housing. The internal and external acoustic insulation capacities of the dwellings and the acoustic insulation capacity of a paired wall were determined according to the regulations regarding acoustic comfort defined by MINVU for social housing.

Materials and methods

\section{Materials}

The tested boards are described in Table 2.

Table 2. Board properties tested for the acoustic reduction index (Rw). Source: Self-Elaboration.

\begin{tabular}{lccccccccc}
\hline \multicolumn{7}{c}{ Table 2. Board properties tested for the acoustic reduction index (Rw). Source: Self-Elaboration. } \\
Sample & $\begin{array}{c}\text { Weight } \\
(\mathrm{kg})\end{array}$ & $\begin{array}{c}\text { Thickness } \\
(\mathrm{mm})\end{array}$ & $\begin{array}{c}\text { Density } \\
\left(\mathrm{kg} / \mathrm{m}^{3}\right)\end{array}$ & $\begin{array}{c}\text { MC } \\
(\%)\end{array}$ & Sample & $\begin{array}{c}\text { Weight } \\
(\mathrm{kg})\end{array}$ & $\begin{array}{c}\text { Thickness } \\
(\mathrm{mm})\end{array}$ & $\begin{array}{c}\text { Density } \\
\left(\mathrm{kg} / \mathrm{m}^{3}\right)\end{array}$ & $\mathrm{MC}(\%)$ \\
\hline PB1 & 13.9 & 18 & 596.3 & 6.8 & PLY 1 & 6.5 & 9 & 557.7 & 8.0 \\
PB2 & 5.5 & 6 & 707.8 & 8.3 & PLY2 & 9.2 & 15 & 473.6 & 8.6 \\
PB3 & 7.4 & 8 & 714.2 & 8.0 & PLY 3 & 5.4 & 9 & 521.2 & 7.3 \\
MDF 1 & 8 & 9 & 686.4 & 6.6 & PLY 4 & 8 & 12 & 514.8 & 8.6 \\
MDF 2 & 6 & 5.5 & 642.4 & 6.5 & HB1 & 3.1 & 3 & 797.9 & 6.3 \\
MDF 3 & 9.2 & 12 & 592.0 & 6.7 & OSB 1 & 8.9 & 11.1 & 572.7 & 5.9 \\
MDF 4 & 11.4 & 15 & 586.8 & 6.2 & OSB 2 & 11.8 & 15.1 & 607.4 & 6.0 \\
\hline
\end{tabular}

One of the emergency housing prototypes designed by Fondef Project D09I1058, developed at the Wood-Based Board Laboratory of the Department of Engineering in Wood and its Biomaterials at the University of Chile in the Commune of La Pintana, Santiago, Metropolitan Region, was selected, manufactured and installed. The walls were fabricated with 64-mm thick SIPs ( $9.5 \mathrm{~mm}$ of OSB per side and $45 \mathrm{~mm}$ of $15 \mathrm{~kg} / \mathrm{m}^{3}$ EPS) (Figure $5 \mathrm{a}$ ). The roof was fabricated with 99 $\mathrm{mm}$ thick SIPs (9.5 mm of OSB per side and $80 \mathrm{~mm}$ of $15 \mathrm{~kg} / \mathrm{m}^{3}$ EPS), calculated for thermal zone 3. The paired wall between 2 contiguous houses was composed of 2 64-mm thick SIPs with a 10-mm thick gypsum hard fiberboard (HB) on each side (Figure 5b). The plans for this dwelling are presented in Figure $5 \mathrm{c}$.

Figure 5. a) Prototype scheme of emergency housing, b) emergency housing, and c) prototype plans of the paired houses installed in Santiago, thermal zone 3. Source: Self-Elaboration.

a)

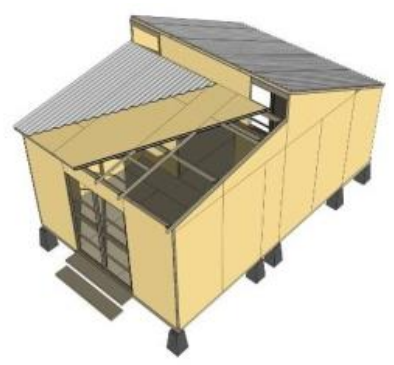

b)

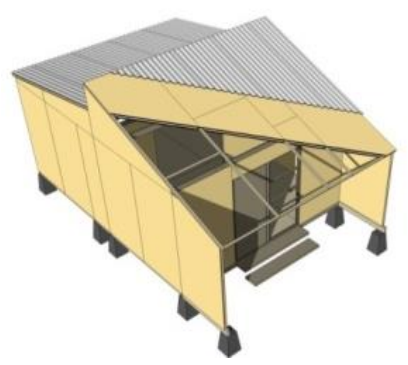

c)

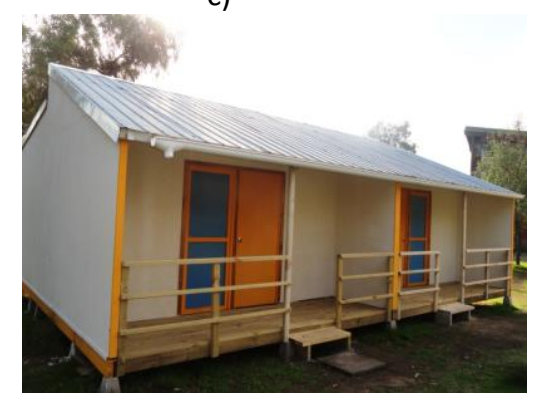




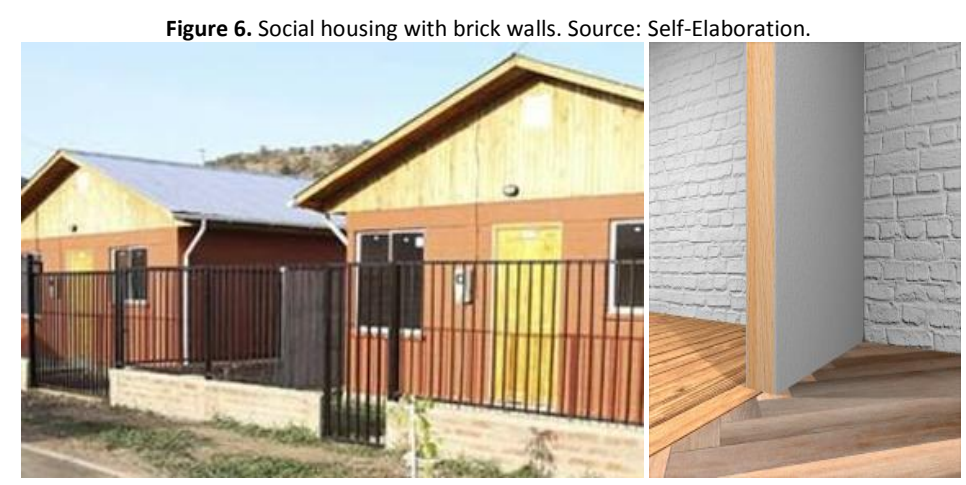

Figure 7. Scheme of the walls for the mediagua. Source: Self-Elaboration.
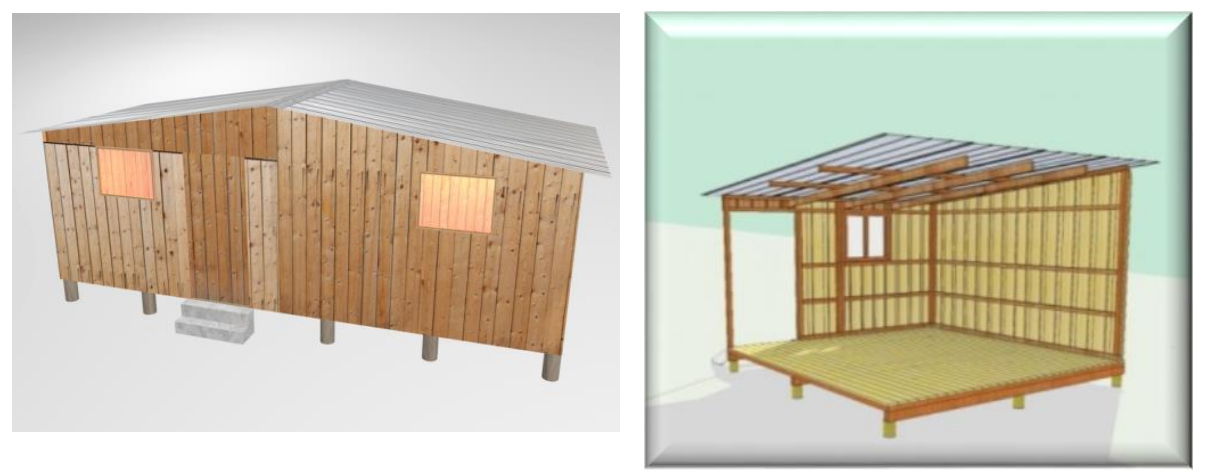

The social housing (Figure 6) located in the municipality of Maipú was selected because, legally, it must comply with the current code (Ministerio de Vivienda y Urbanismo, 2013). Its perimeter is built with $29 \times 14 \times 7$ cored bricks with a thickness of $1 \mathrm{~cm}$, a density of $1006 \mathrm{~kg} / \mathrm{m}^{3}$, a weight of $2.9 \mathrm{~kg}$, a thermal resistance of $0.56 \mathrm{~m}^{2} / \mathrm{W}$ and a thermal transmittance of $1.8 \mathrm{~W} / \mathrm{m}^{2} \mathrm{~K}$. The internal division specifications are as follows: the partitions are made with uprights of unsealed $12 \%$ dry wood, top and bottom supports with dimensions of $2 \times 1$ ", and a firewall with dimensions of $1 \times 1 "$, and coatings and filler between the spaces; additionally, both sides are covered by 15-mm thick gypsum board with a density of $800 \mathrm{~kg} / \mathrm{m}^{3}$ and thermal conductivity of $0.19 \mathrm{~W} / \mathrm{Mk}$ (Volcan, n.d.). The roof is slate on wooden trusses and dry unsealed $4 \times 6$ " beams, with a plasterboard ceiling.

Figure 8. a) Distribution of sound meter and speaker positions. Source: Self-Elaboration. b) Scheme of the SIP paired wall of the red section of Figure 8a.

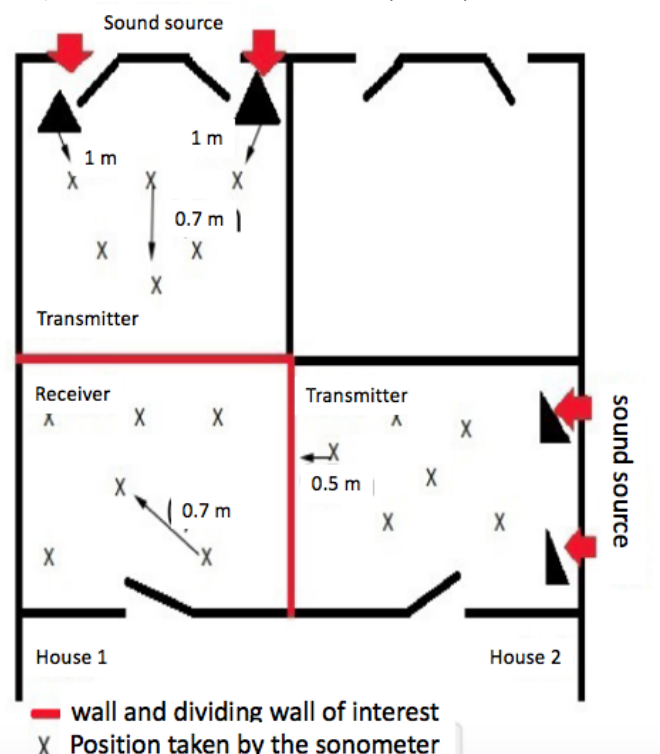

a)

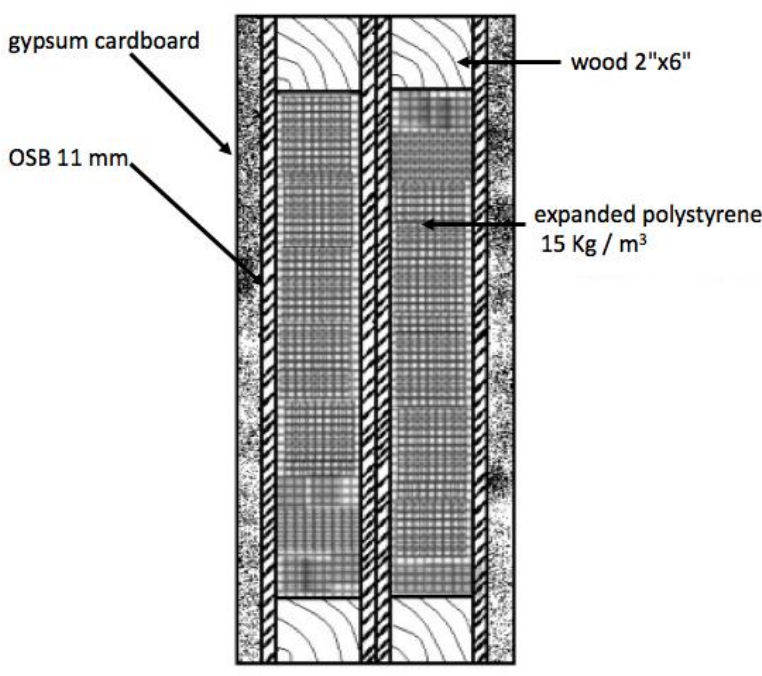

b) 
The mediagua, located in the commune of La Pintana, is formed by partitions made of pine wood (Pinus radiata D. Don)

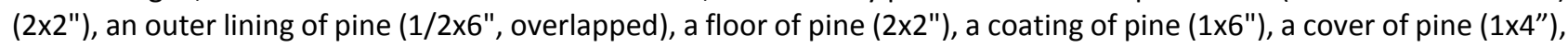
a waterfront (2x2"), felt (10 LB) and zinc (5 V $35 \mathrm{~mm}$ ). Dimensions: $2.20 \mathrm{~m}$ high, $3 \mathrm{~m}$ wide and $6 \mathrm{~m}$ long (Figure 8).

The test used a Larson Davis LTX1 Model 831 Sound Level Meter equipped with a comprehensive firmware platform that allowed us to evaluate the ambient noise, perform acoustic measurement and construct the reverberation time for the real-time analysis of sound in the 1/3-octave band. The employed speaker was 12" (250 W with USB and a Larson Davis CAL 200 Sound Level Calibrator), with a precision microphone sound level and an output level of 94 or $114 \mathrm{~dB}$ at a 1-kHz frequency. The accuracy was calibrated by referring to the National Institute of Standards and Technology (NIST).

\section{Method}

The acoustic reduction index of panels (Rw) corresponds to the difference in sound levels between the emission enclosure and the sound-receiving area, corrected for the ratio between the area of the element tested and the equivalent absorption area of the receiving enclosure. Experimental Rw determination for the boards and SIPs was carried out in the laboratory according to the standard NCh 2786 (Instituto Nacional de Normalización, 2003), considering that greater acoustic insulation is obtained from dense materials and not from low-density materials such as expanded polystyrene; accordingly, the acoustic insulation is mostly provided by the OSB. The tests were carried out at the Acoustic Laboratory of the Center for Research, Development and Innovation of Structures and Materials ("Centro de Investigación, Desarrollo e Innovación de Estructuras y Materiales", IDIEM) of the University of Chile, located at Plaza Ercilla \#883, Santiago. This laboratory has a sample holder frame that receives a sample of $0.7 \mathrm{~m}^{2}$. Once assembled, the laboratory is divided into 2 adjacent enclosures, transmitter and receiver, whose volumes are 210 and $39.2 \mathrm{~m}^{3}$, respectively. The separation of these enclosures is the tested element. Each $1.85 \mathrm{~m}$ high $\times 0.70 \mathrm{~m}$ wide specimen was placed in the doorway and fastened with bolts to the concrete wall. The measurements were made according to ISO 140-3. Pink noise was generated in the emission room, establishing a sound pressure level (NPS) emission of $106 \mathrm{dBA}$ on average in broadband. The NPS was measured with a sound level meter in both rooms, with 6 fixed microphone positions and 2 source positions ( 12 total measurements per room). The reverberation time of the receiving room was determined according to the interrupted source method, using 4 fixed sound level positions, 1 source position and 2 decays per position ( 8 measurements in total). The level of background noise in the receiving room was determined to be $39.5 \mathrm{dBA}$. All measurements were made in $1 / 3$ octave bands, between the bands of $100 \mathrm{~Hz}$ and $5000 \mathrm{~Hz}$. In all acoustic measurements, the signal-to-noise ratio was greater than $15 \mathrm{~dB}$. This study was based on the standards (Instituto Nacional de Normalización, 2002) (for field measurements) and (Instituto Nacional de Normalización, 2000) for acoustic insulation evaluation in laboratories.

The determinations of the acoustic behavior of the houses were made according to (Instituto Nacional de Normalización, 2003), in which a pink noise was generated, characterized by a spectral density inversely proportional to the frequency and adjusted to the characteristics of the transmitting and receiving rooms of each room evaluated (Figure 8).

The acoustic insulation was measured for the paired wall and the dividing wall of the room dividing the room into 2 rooms, using the sound source to transmit and the sound level meter to receive noise, establishing a spatial average of NPSs in a broad band of 107 dBA. Subsequently, the NPS was measured in both rooms using the sound level meter; 6 fixed microphone positions and 2 source positions were set ( 12 total measurements per room). The reverberation time of the receiving room was determined according to the interrupted source method, using 4 fixed sound level positions, 1 source position and 2 decays per position ( 8 measurements in total). In addition, the background noise level was recorded in the receiving room to calculate the difference in $\mathrm{dBA}$ before and after the noise; the recording time was 30 seconds or until the NPS was constant. The determinations were performed in 1/3-octave bands, between the bands of $100 \mathrm{~Hz}$ and $5000 \mathrm{~Hz}$.

These data allow the determination of the apparent acoustic reduction index ( $\left.R^{\prime}\right)$, which corresponds to 10 times the logarithm in base 10 of the ratio between the acoustic power $W_{1}$, which affects the construction element under test, and the total acoustic power signal transmitted to the reception area; for the total acoustic power signal, the sound power $W_{3}$ flowing through the other components of the side constructions are added to the acoustic power $W_{2}$ that flows through the separation element, and $R^{\prime}$ is expressed in decibels ( $d B$ ).

$$
R^{\prime}=10 \log \frac{W_{1}}{W_{2}+W_{3}}
$$


The minimum distances for the microphones placed in the rooms, according to standard 2785 (Instituto Nacional de Normalizacion, 2002), were $0.7 \mathrm{~m}$ between the microphones, $0.5 \mathrm{~m}$ between any microphone and the edges or diffusers of the enclosure and $1 \mathrm{~m}$ between any microphone and the source of the noise. The sound sources were located in the transmitting room, generating a diffuse acoustic field at least $0.5 \mathrm{~m}$ from the edge of the room. The location of the source emitter outside was $5 \mathrm{~m}$. A data interpretation program was developed in an Excel calculation template to obtain the acoustic reduction index, with the following measurements of the sound level meter as inputs: Emitter1, Emitter2, Receiver1, Receiver2, RF, TR1 and TR2 (Figure 9). Along with a description of the components of the partition, including the volume, surface, thickness and density, the result was saved in as a Word file, PDF or as another file format.

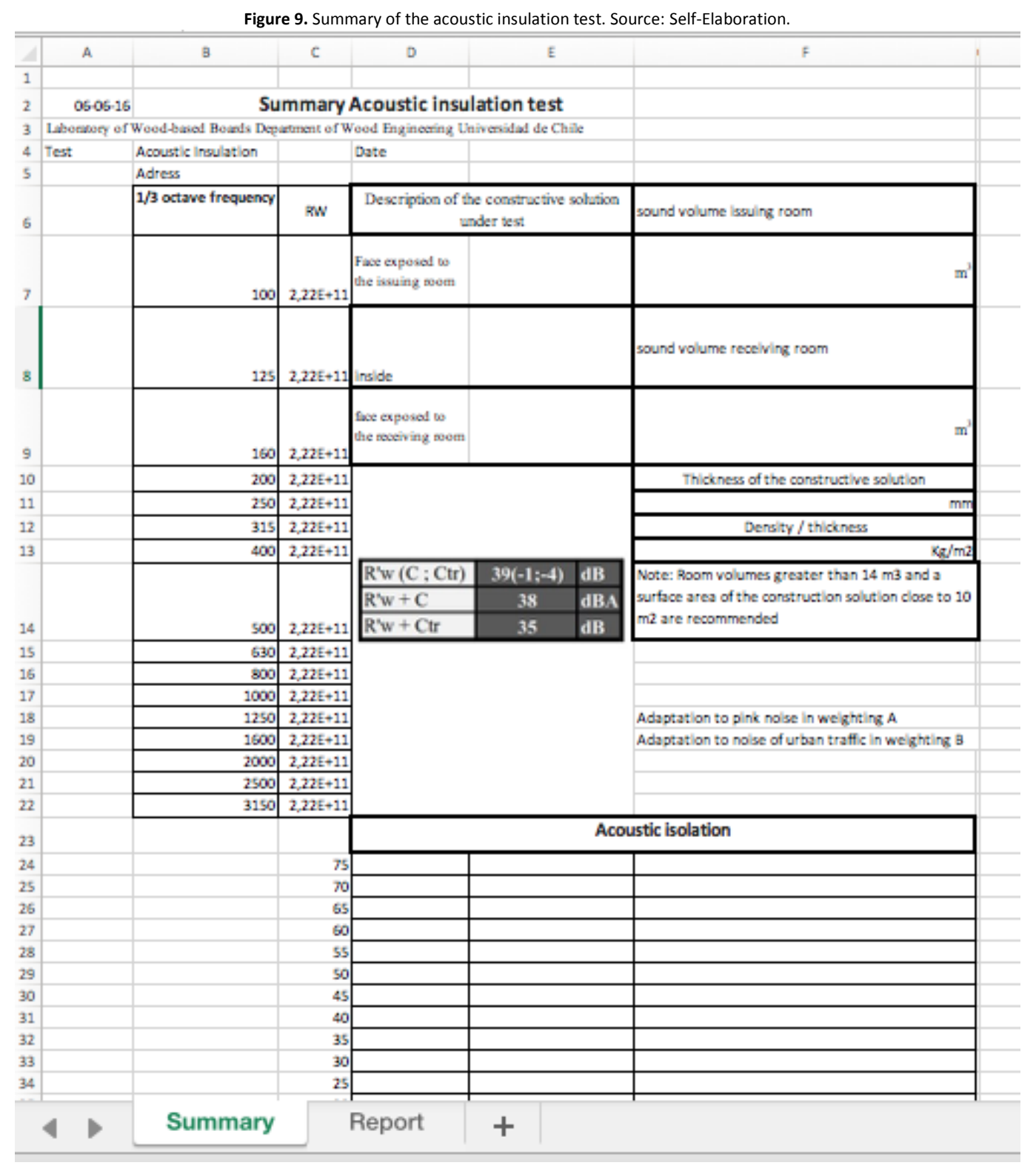

The red reference curve in Figure 11 is the apparent acoustic reduction index ( $\left.\mathrm{R}^{\prime}\right)$ or difference in levels between the emitter and the receiver, corrected for the ratio of the tested element area to the equivalent absorption area of the receiving enclosure. It was determined experimentally in the laboratory according to standard 2786 (Instituto Nacional de Normalización, 2003). The $\mathrm{R}^{\prime}$ of a construction element is measured in situ and depends on both the indirect transmissions and the acoustic reduction index $(\mathrm{Rw})$ of a construction element; it is also measured in the laboratory but does not include indirect transmissions. Subscript A means that the values have been weighted to curve $A$ (incident pink noise). There is no mathematical relationship between them; it is only a question of comparing the values obtained in situ to those predicted by laboratory tests. 
The evaluation results of the acoustic reduction index (Rw) of the boards are shown in Figure 10 and Table 3.

Figure 10. Board acoustic isolation. Frequency band in $1 / 3$ octave $\left(\mathrm{FBt}_{h} \mathrm{O}\right)$. Source: Self-Elaboration.

\section{MDF \& HB acoustic isolation}

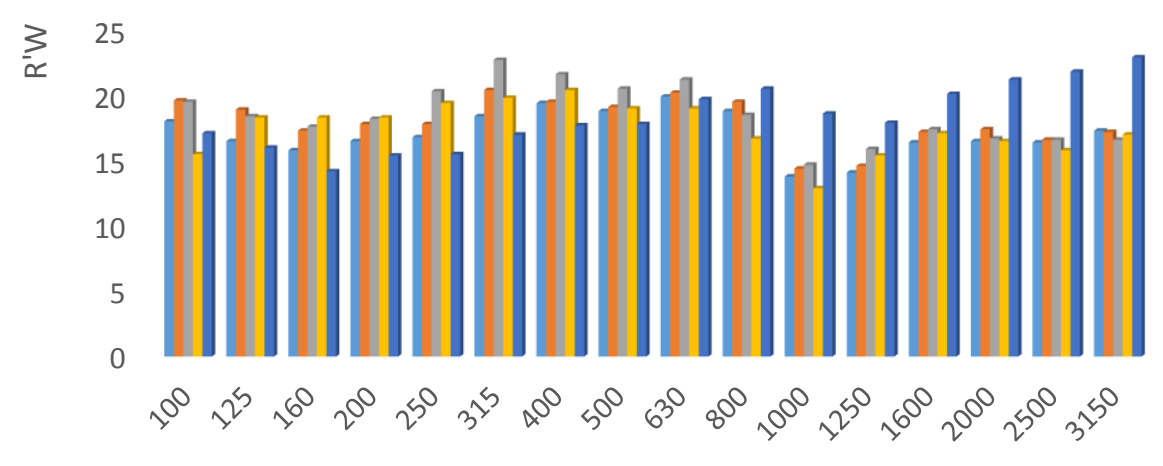

Frecuency $1 / 3$ octaves

MDF $5.5 \mathrm{~mm} \quad \operatorname{MDF} 9.5 \mathrm{~mm} \quad \operatorname{MDF} 12 \mathrm{~mm} \square \mathrm{MDF} 15 \mathrm{~mm} \quad \mathrm{HB} 3 \mathrm{~mm}$

Ply acoustic isolation

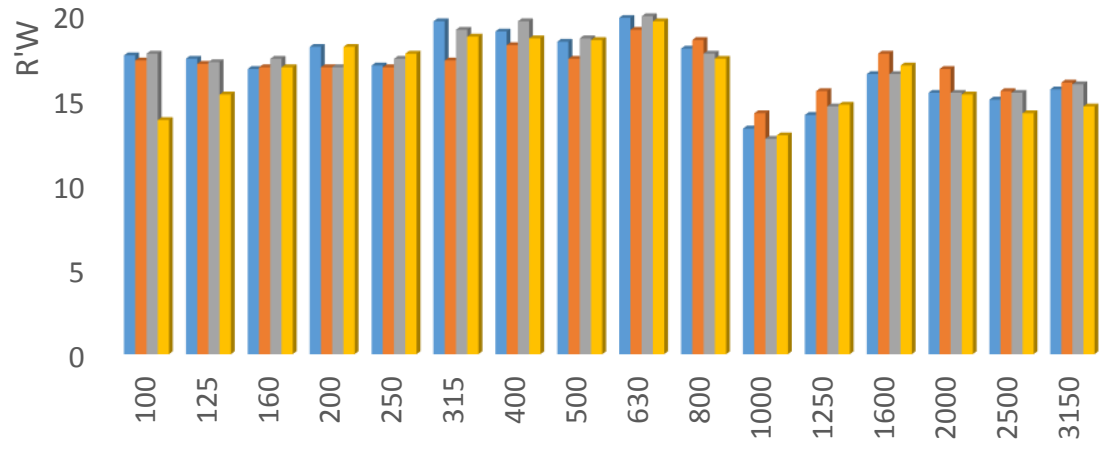

Frecuency $1 / 3$ octaves

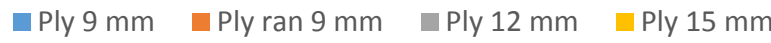

PB acoustic isolation

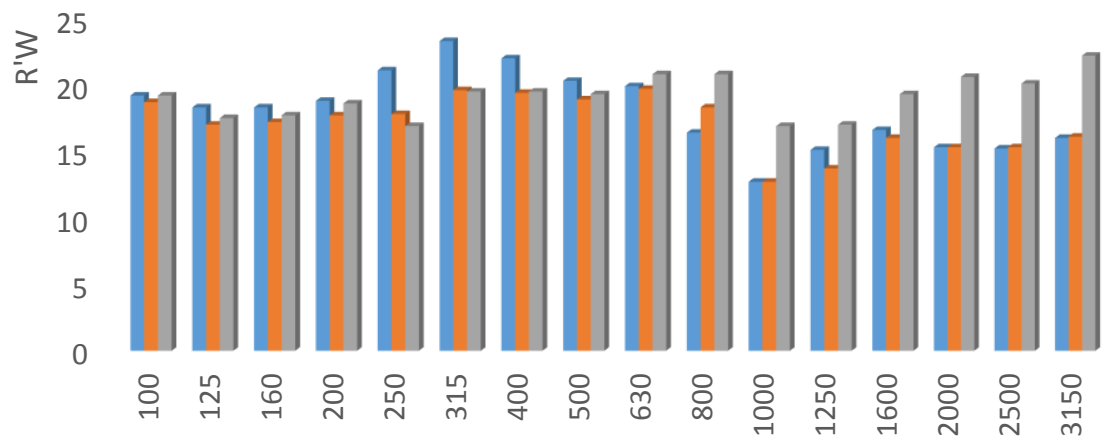

Frecuency $1 / 3$ octaves

$\square \mathrm{PB} 18 \mathrm{~mm} \quad \square \mathrm{PB} 8 \mathrm{~mm} \quad \square \mathrm{PB} 6 \mathrm{~mm}$ 


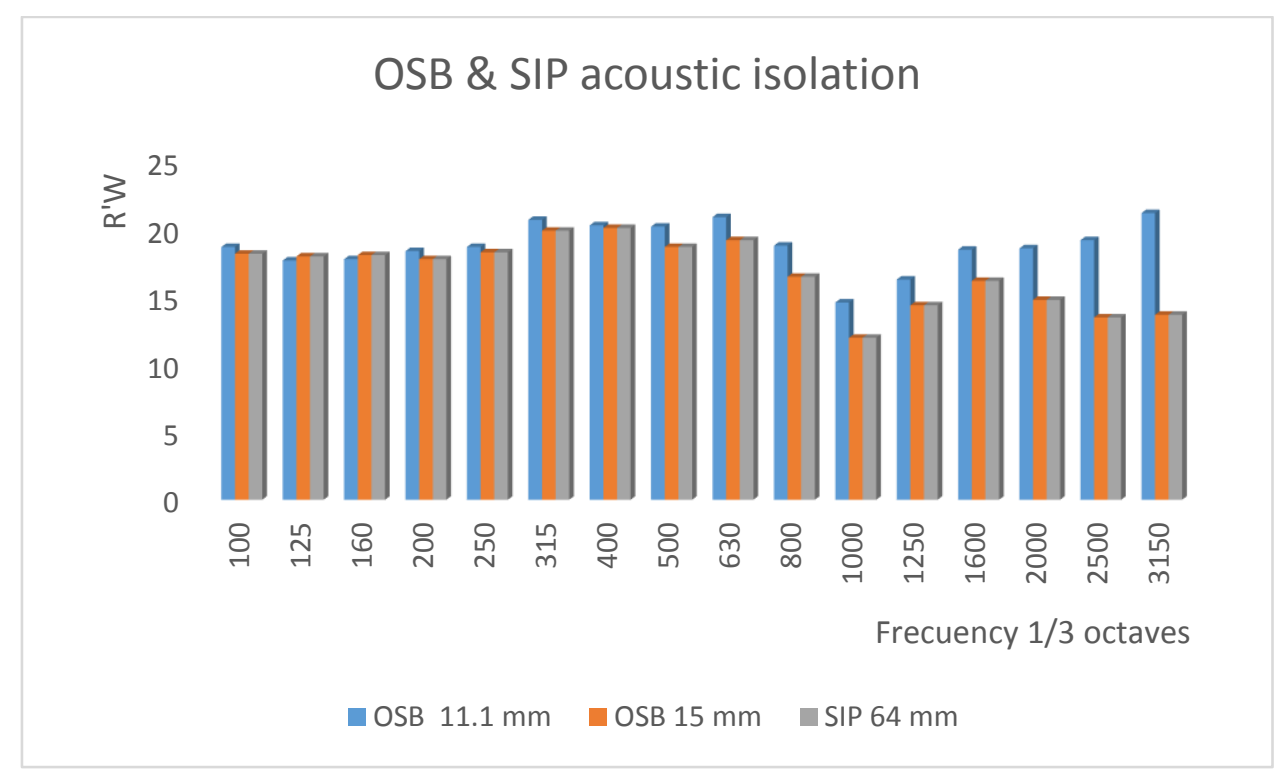

where Rw is the overall acoustic reduction index. Based on the frequency of $500 \mathrm{~Hz}, \mathrm{Rw}$ (c, ctr) characterizes the acoustic properties of the material. Rw indicates the difference in sound levels between the two sides of a partition; for a spectrum with energy points lower than $500 \mathrm{~Hz}$, the Rw is corrected, with C being corrected for pink noise and Ctr being corrected for traffic noise.

The results are between 15 and $20 \mathrm{~dB}$; as the results are in logarithmic form, they do not indicate a linear change but are expressed such that differences of 3 or more units are significant. Figure 10a-m is a graphical interpretation of Table 3.

Table 3. Measurement of acoustic reduction index (Rw) for MDF; Plywood, PB, OSB, and HB [dB]. Source: Self-Elaboration.

\begin{tabular}{lccccccc}
\hline Sample & RW $(\mathrm{C} ; \mathrm{Ctr})$ & $\mathrm{RW}+\mathrm{C}[\mathrm{dBA}]$ & $\mathrm{RW}+$ Ctr & Sample & $\mathrm{RW}(\mathrm{C} ; \mathrm{Ctr})$ & $\mathrm{RW}+\mathrm{C}[\mathrm{dBA}]$ & $\mathrm{RW}+\mathrm{Ctr}[\mathrm{dB}]$ \\
\hline MDF 1 & $17(0 ; 0)$ & 17 & 17 & PLY1 & $16(0 ; 0)$ & 16 & 16 \\
MDF 2 & $17(-1 ;-1)$ & 16 & 16 & PLY 2 & $16(-1 ; 0)$ & 15 & 16 \\
MDF 3 & $17(0 ; 0)$ & 17 & 17 & PLY 3 & $17(-1 ;-1)$ & 16 & 16 \\
MDF 4 & $16(0 ; 0)$ & 16 & 16 & PLY 4 & $16(0 ; 0)$ & 16 & 16 \\
PB 1 & $16(0 ; 0)$ & 16 & 16 & OSB 1 & $19(-1 ;-1)$ & 18 & 18 \\
PB 2 & $20(-1 ;-1)$ & 19 & 19 & OSB 2 & $15(0 ; 0)$ & 15 & 15 \\
PB 3 & $16(0 ; 0)$ & 16 & 16 & HB1 & $20(0 ;-1)$ & 20 & 19 \\
\hline
\end{tabular}

When boards include fibers in the horizontal plane and the distribution of smaller particles or fibers is more uniform, sound transfers through them more easily. An analysis of the variance in the boards determined that the density was directly related to the acoustic insulation and that the increase in thickness was not related to a lower sound transmission; hence, presumably, better results are not obtained by increasing the thickness. In insulation architecture, the use of high-density and low-thickness sheets (rubber, fabrics or tapestries) are used depending on whether the partition walls are required to dissipate, direct, absorb or isolate the sound. In particular, a combination of board and rubber is advisable.

HB and PB presented higher R'w values and had densities $\geq 700 \mathrm{~kg} / \mathrm{m}^{3}$; the homogeneous composition of particles and adhesive formed a barrier to traffic noise. Medium-density fiberboard (MDF) is composed of smaller and more uniform fibers that, although denser, did not give a better $R^{\prime} w$ because of the fiber lumens that create tiny air spaces in which the noise moves more easily. Thus, the sound travels via a path of uniform ducts, with fewer obstacles than those offered by contrasting plates, with the flakes being distributed in different directions and with densities. Boards with between 16 and $17 \mathrm{~dB} \mathrm{R}^{\prime} w$ are formed by segments of wood of larger dimensions. In OSB, the wood chips mixed with adhesive are oriented orthogonally. In Plywood, the irregular plates are arranged orthogonally, forming structures that obstruct the passage of sound, causing more absorption than transmission.

Caballe et al. (2017) investigated the capacity for predicting the structural quality of the wood in standing trees using sonic methods, measuring the growth, tree shape, wood density and propagation speed of longitudinal and radial sonic 
waves and testing the shaft under flexion to determine the modulus of elasticity (MOE) and modulus of rupture (MOR). By means of multivariate regression models, the study attempted to predict these properties. Three models had prediction accuracies of $50 \%$, and the slenderness, tree inclination and propagation velocity of the longitudinal sonic wave are the variables that best relate to the MOR and the MOE. These results associated with the internal structure could be directly correlated with the insulation capacity of boards, but this theory still needs to be tested.

The acoustic evaluation of dwellings is presented in Table 5 and Figure 11a-d. The test conditions are described in Table 4. In the SIP house, a simple SIP divided 2 interior rooms, and the paired panel whose function was to comply with the fire resistance standard (SIP + plasterboard per side), divided the room from the adjacent house (Figure 8b). For the brick social housing, we evaluated the wall paired with the adjacent house and the interior partition of wood and gypsum board. In the mediagua, the entire structure is made of unlined wood with spaces between open boards (Figure 5). In all cases, the space was divided into 2 environments: the emission room and reception room.

\begin{tabular}{llcl} 
& Table 4. Specific conditions for conducting the tests. Source: Self-Elaboration. \\
\hline Element & Characteristics & \multicolumn{2}{c}{ Volume $\left(\mathrm{m}^{3}\right)$} \\
\hline SIP wall & Surface $\left(\mathrm{m}^{2}\right)$ & 11.85 & Issuer 34 \\
& Thickness $(\mathrm{mm})$ & 64 & Receiver 28.68 \\
& Density $\left(\mathrm{kg} / \mathrm{m}^{3}\right)$ & 97 & \\
Dividing wall: & Surface $\left(\mathrm{m}^{2}\right)$ & 6.95 & Issuer 62.68 \\
SIP panel + plasterboard & Thickness $(\mathrm{mm})$ & 128 & Receiver 28.68 \\
& Density $\left(\mathrm{kg} / \mathrm{m}^{3}\right)$ & 194 & \\
Dividing wall: brick & Surface $\left(\mathrm{m}^{2}\right)$ & 9.6 & Issuer 31.94 \\
& Thickness $\left(\mathrm{mm}^{3}\right)$ & 140 & Receiver 58.08 \\
& Density $\left(\mathrm{kg} / \mathrm{m}^{3}\right)$ & - & \\
Plasterboard wall & Surface $\left(\mathrm{m}^{2}\right)$ & 97.92 & Issuer 26.13 \\
& Thickness $\left(\mathrm{mm}^{2}\right)$ & 60 & Receiver 21.38 \\
& Density $\left(\mathrm{kg} / \mathrm{m}^{3}\right)$ & - & \\
Mediagua wall & Surface $\left(\mathrm{m}^{2}\right)$ & 6.6 & Issuer 19.8 \\
& Thickness $\left(\mathrm{mm}^{2}\right)$ & 60 & Receiver 19.8 \\
& Density $\left(\mathrm{kg} / \mathrm{m}^{3}\right)$ & - & \\
\hline
\end{tabular}

Table 5. Divider wall house evaluation of acoustic isolation. Source: Self-Elaboration.

\begin{tabular}{|c|c|c|c|c|c|c|c|c|}
\hline $\begin{array}{l}1 / 3 \\
\text { octave } \\
\text { band } \\
\text { frequency }\end{array}$ & $\begin{array}{c}\text { Wall dividing } \\
\text { environment } \\
\text { mediagua }\end{array}$ & $\begin{array}{c}\text { 64-mm } \\
\text { SIP }\end{array}$ & $\begin{array}{c}\text { Environment } \\
\text { separator } \\
\text { SIP shelter }\end{array}$ & $\begin{array}{l}\text { Wall } \\
\text { dividing } \\
\text { SIP } \\
\text { shelter }\end{array}$ & $\begin{array}{c}\text { Wall } \\
\text { dividing } \\
\text { plasterboard } \\
\text { social } \\
\text { housing }\end{array}$ & $\begin{array}{l}\text { Wall } \\
\text { dividing } \\
\text { brick } \\
\text { social } \\
\text { housing }\end{array}$ & $\begin{array}{l}\text { Paired } \\
\text { brick } \\
\text { wall }\end{array}$ & $\begin{array}{c}\text { Reference } \\
\text { rules }\end{array}$ \\
\hline 100 & 3.4 & 20 & 27.1 & 29.1 & 28.7 & 30.6 & 25.2 & 45 \\
\hline 125 & 4.1 & 18.7 & 24.5 & 18.4 & 25.2 & 29.4 & 24.5 & 45 \\
\hline 160 & 3.3 & 19.7 & 26.1 & 27.1 & 26 & 30.3 & 23.4 & 45 \\
\hline 200 & 4.7 & 21.1 & 27.6 & 28.5 & 31.1 & 31.8 & 24.2 & 45 \\
\hline 250 & 5.9 & 23.3 & 25.8 & 29 & 35.4 & 33.9 & 24.8 & 45 \\
\hline 315 & 5.8 & 24.4 & 27.3 & 30 & 32.3 & 35 & 25.9 & 45 \\
\hline 400 & 5 & 22.2 & 26.9 & 30.7 & 34.1 & 32.9 & 26.7 & 45 \\
\hline 500 & 4.7 & 21.1 & 27.7 & 33.3 & 34.3 & 31.7 & 29.2 & 45 \\
\hline 630 & 3.8 & 19.4 & 29 & 37 & 37.1 & 30.1 & 32.2 & 45 \\
\hline 800 & 6.1 & 16.5 & 29.1 & 39.6 & 40.6 & 27.1 & 34.9 & 45 \\
\hline 1000 & 5.5 & 13.4 & 28.3 & 42.5 & 41 & 24.1 & 37.4 & 45 \\
\hline 1250 & 5.9 & 15 & 28.6 & 45.9 & 43.4 & 25.6 & 41.1 & 45 \\
\hline 1600 & 7.2 & 16.7 & 32.1 & 46.8 & 43.5 & 27.3 & 42.1 & 45 \\
\hline 2000 & 7.5 & 15.9 & 33.1 & 47.6 & 42.1 & 26.5 & 42.7 & 45 \\
\hline 2500 & 7.1 & 16.1 & 33.3 & 49.5 & 38.8 & 26.7 & 43.5 & 45 \\
\hline 3150 & 7.2 & 17.4 & 33.6 & 51.5 & 37 & 28 & 44.5 & 45 \\
\hline
\end{tabular}




\section{Wall acoustic isolation}

$\underset{\Upsilon}{\nwarrow}$

60

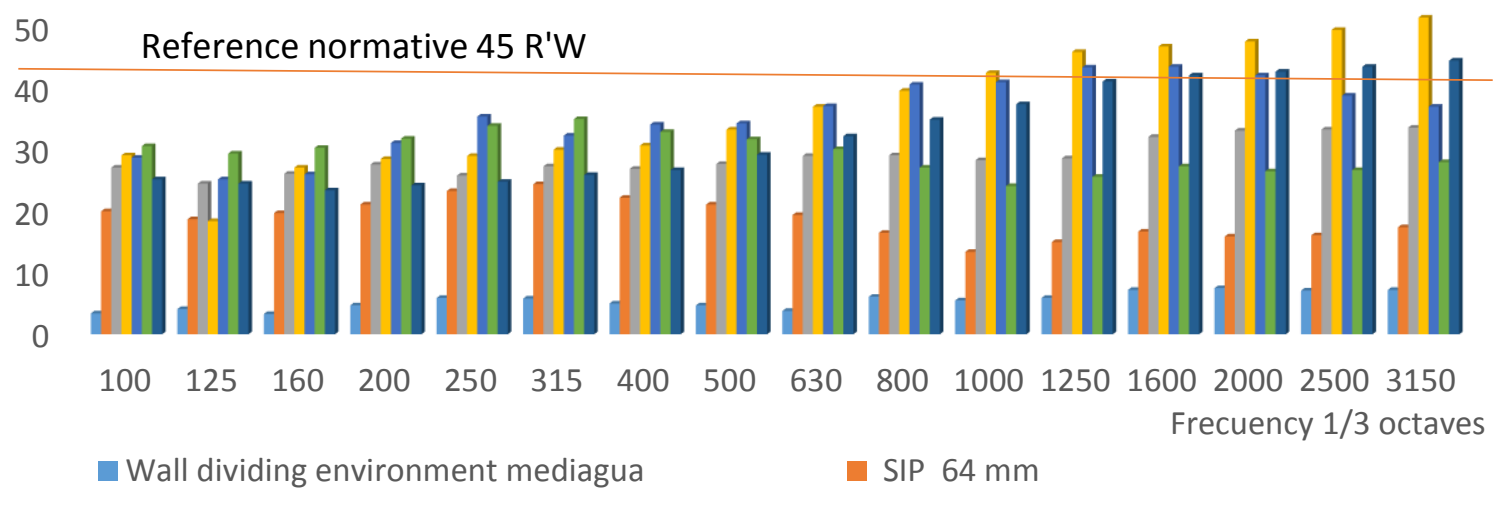

Environment separator Shelter SIP

Wall dividing Shelter SIP

Wall dividing plater social housing

Wall dividing brick social housing

Paired brick wall

Figure 12. a) Double bolt wall, b) stepped wall, c) single wall mounted on one side, d) typical floor/roof system, e) sound transmission channels. Source: Self-Elaboration.

a)

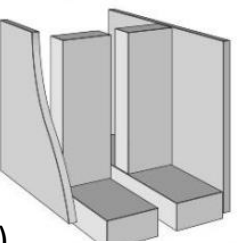

c)

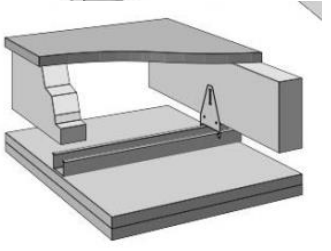

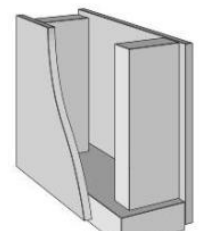

b)

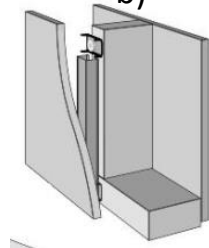

d)

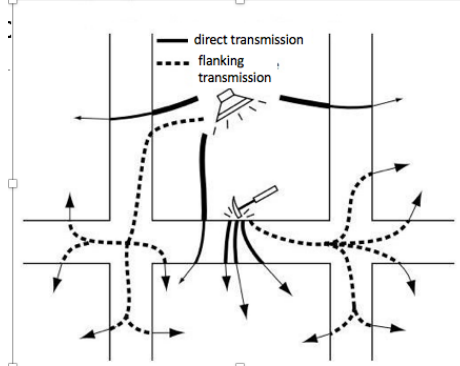

e)

Figure 11a shows the $R^{\prime} w$ and $\left(R^{\prime} w+C\right)$ results of the panel for the mediagua, with $6 \mathrm{~dB}$ and $6 \mathrm{dBA}$. The deficit of the material is evidenced, as it does not present the thickness or density necessary for correct isolation. The results are approximately constant, which indicates that the noise does not have barriers that prevent its transmission by media.

Figure $11 b$ shows the $R^{\prime} w$ and $\left(R^{\prime} w+C\right)$ results of the SIP, with $30 \mathrm{~dB}$ and $30 \mathrm{dBA}$. The insulating behavior indicates that the sound does not show noticeable variations; rather, it is represented by a straight line and approximately constant, although unfavorable differences occur on one occasion.

Figure 11c shows the $R^{\prime} w$ and $\left(R^{\prime} w+C\right)$ results of the paired brick wall of the social housing, with $42 \mathrm{~dB}$ and $41 \mathrm{dBA}$. The passage of the noise is similar to that for the SIP, but the changes that the sound undergoes through the wall are more noticeable, as the line clearly rises and falls. The decrease is noticeable in 3 sectors, of which only 2 coincide with unfavorable differences. Only at the beginning of the line is there a decrease, which is due to the change in materials.

In Figure $11 d$, the $R^{\prime} w$ and $\left(R^{\prime} w+C\right)$ results of the partition wall SIP + gypsum board, with $39 \mathrm{~dB}$ and $38 \mathrm{dBA}$, are shown. The behavior of the sound increases as a result of the increase in the frequency band of the $1 / 3$ octave; only between 
$250 \mathrm{~Hz}$ and $800 \mathrm{~Hz}$ is there a decrease, which coincides with unfavorable differences indicated in the lead bars (they show a perturbation provoked by the noise frequently different from that established by the norm, which does not affect the study of the sound isolation). The addition of gypsum produces an improvement in the acoustic insulation, as noise encounters more obstacles due to the greater density.

Figure 11 e shows the $R^{\prime} w$ and $\left(R^{\prime} w+C\right)$ results of the gypsum wallboard, with $40 \mathrm{~dB}$ and $39 \mathrm{dBA}$. Similar to the brick dividing wall, the difference is due to the lower R'w. The plaster does not present better insulation than the brick (different density); both have the same dimension and thickness.

\section{Discussion}

The density of the materials, $\geq 500 \mathrm{~kg} / \mathrm{m}^{3}$, is a determinant in the results, making it difficult for noise to pass to the adjoining room. Another determining factor is the type of union between elements (sealed with stucco and paint), hindering the leakage of noise. The attenuation is close to the regulation stipulated by the MINVU ( $45 \mathrm{~dB}$ ) but does not comply with it.

The SIP presented results similar to those of the brick walls, explained by the density composition and layout of the OSB, representing an obstacle for sound waves and making it difficult for sound to cross freely from side to side, although a problem was evidenced in all cases regarding joints (door, windows and floor). Thus, terminations with suitable millimeter-scale joints should be implemented to avoid acoustic bridges that encourage the escape of noise to other spaces become important; safeguarding these aspects, the thermal and acoustic insulation of housing can be improved (APA, 2017).

The quality of the wood and the lack of technical construction specifications for the mediagua lead to the criteria for a dwelling and its habitability, in particular, acoustic insulation, not being met due to defects such as curvature, twisting, bad dimensioning and even missing parts in the tables. In addition, the partition itself does not have any type of inner lining, so the wooden boards are open, which does not fulfill the minimal isolation in any of its enclosures: walls, ceilings or floor.

In general, although the dwellings must have a verifiable index that differentiates them technically and/or allows them to be certified according to their compliance; in reality, architects or engineers are not required to perform simulations to verify that the chosen construction materials comply with the norm.

There are lists and manuals of construction acoustic solutions, both in Chile and abroad. Some relevant aspects to keep in mind for any wall or floor that separates houses is that it must have resistance to the passage of 2 types of sound, from sources such as the environment, people talking, musical instruments and loudspeakers and from sources of impact, such as moving furniture and reverberating water pipes. In practical situations, the lowest audible emission is 3 decibels, while a variation in 1 or 2 decibels is undetectable, as noted by the multi-residential timber framed construction. Transmission loss can be achieved by increasing the mass of the wall system and/or ceiling (heavier elements vibrate less and produce less sound energy radiation).

Less homogeneous materials offer more resistance to the transmission of sound because the sound crosses more obstacles.

One of the most inexpensive and effective ways to achieve the loss of sound transmission is the use of double-layer construction, i.e., 2 layers of material separated by an air gap. This ideal system, without structural connection between the layers, would cause the air cavity to provide a greater reduction in noise, as only a fraction of the energy of the sound is transmitted from the surface to the cavity and back to the surface. With structural coupling between the layers, sound vibrations can be transferred through the structure (the acoustic equivalent of an electrical short circuit). For the construction of lightweight walls, there are several practical ways of reducing the mechanical connections between the partition layers. These techniques include using double bolts (double or single walls), 2 independent wall panels (Figure 12a), staggered pegs separated from rows, studs that share common wall plates (Figure 12b) or a row of posts with elastic metal channels that support wall coverings on one or two sides (Figure 12c), as suggested by (Forest and Wood Products Australia, 2012). With staggered framing walls, direct sound transmission is eliminated through stud bolts, but the top and bottom plates are shared, thus allowing some "short circuiting" of the sound energy (Figure 12d).

By filling the cavity with an absorbent insulation material (cellulose fiber, glass or mineral wool), a greater transmission loss is achieved when the material is thick. The sound-absorbing material must be at least $50 \mathrm{~mm}$ thick and have a 
minimum density of $12 \mathrm{~kg} / \mathrm{m}^{3}$, or $2 / 3$ of the wall/ceiling cavity. The addition of absorbent material to the cavity is beneficial only if the structural connections between the surfaces do not transmit vibration energy. In a building with rigidly connected components, sound energy can be transmitted through the ceiling, wall and floor to adjoining rooms. Sound vibrations are radiated from all surfaces (Figure 12e) and for all building materials (brick, concrete, wood, steel, etc.). To outflank the paths, it must be ensured that the only significant sound transmission path is through the material by minimizing energy transmission and improving the solid joints between the material and the surrounding structure.

The acoustic insulation in these 3 housing types can be improved by making use of conditioning or construction solutions to improve the acoustic reduction index; the MINVU has published a list with various types of improvement for the partitions and walls present in houses. Below, a selection of the solutions that best fit the walls present in the studied dwellings is given.

For the panels tested, it was determined that at higher density, there is a higher acoustic reduction index. OSB reached an Rw of $19 \mathrm{~dB}, \mathrm{HB}$ and PB reached an Rw of $20 \mathrm{~dB}$, and MDF and Plywood reached Rw values of 16 and $17 \mathrm{~dB}$. Although the boards had positive Rw values for the sound insulation, they are still insufficient for regulatory compliance, so additional noise insulation materials should be used.

The transitory emergency dwellings called mediaguas have a structure that does not meet the acoustic comfort regulations, obtaining the lowest result $(6 \mathrm{~dB})$.

The SIP exhibited acoustic results close to the standard ( $39 \mathrm{~dB}$ ) but does not comply with the acoustic comfort regulations.

For social housing, only the perimetric walls approach the minimum acoustic comfort required by the ordinance $(42$ $\mathrm{dB}$; ; the properties of the internal walls of the house fall several decibels below the minimum.

In SIP and brick social housing, the external walls presented a better Rw than the internal walls because the densities differ, with the denser walls offering better acoustic insulation.

Acknowledgments

The authors wish to thank the Fondef program, of the Chilean National Commission for Research in Science and Technology (CONICYT), for financial support in the development of the emergency housing prototype through grant D09I1058.

References

APA. (2017). Acoustic Performance of All-Wood Floor Systems, (lic), 1-6. https://www.apawood.org/publication-search?q=t230\&tid=1

Bucur, V. (1996). Acoustics of Wood. Materials Science Forum, 210-213, 101-108. https://doi.org/10.4028/www.scientific.net/MSF.210-213.101

Bustos, F. (2011). Revisión y Propuesta de Modificación de la norma NCH 352 of 61 . Condiciones acústicas que deben cumplir edificios de uso no habitacional. Retrieved from http://www.scielo.cl/scielo.php?script=sci_arttext\&pid=S0717-69962013000200014\&lng=en\&nrm=iso\&tlng=en

Caballé G., Mansini R., Santaclara O., Gonçalves R., Guaita M., Lario Leza F., Merlo E. (2017). Capacidad de predicción de calidad estructural de la madera con métodos sónicos desde edades tempranas. Trabajo in extenso presentado en II Congreso Latinoamericano de Estructuras de Madera. II Congreso Ibero-Latinoamericano de la Madera en la Construcción (CLEM CIMAD). Argentina. 8p. http://lemej.unnoba.edu.ar/wpcontent/uploads/clemcimad17/Actas_CLEM_CIMAD_2017.pdf

Forest and Wood Products Australia. (2012). Timber-framed Construction for Multi-residential Buildings Class 2, 3 \& 9c. Technical Design Guide 02.

Fundacion Chile. (2004). Características Acústicas de Viviendas Sociales Urbanas Definición de Estándares y Recomendaciones de Diseño.. Santiago Chile: Instituto de la Vivienda Facultad de Arquitectura y Urbanismo, Universidad de Chile. 124 p. http://libros.uchile.cl/files/presses/1/monographs/664/submission/proof/files/assets/common/downloads/Bienestar\%20habitacional\%20.pdf

Garay Moena, Rose-Marie; Pfenniger Bobsien, Francis; Tapia Zarricueta, Ricardo y Larenas Salas, Jorge (2014). Viviendas de emergencia, bases técnicas y normativas. Vol 3. Especificaciones técnicas. Santiago: Universidad de Chile, $45 \quad p$. http://repositorio.conicyt.cl/browse?type=folio\&value=D0911058

Garay, R., \& Henriquez, M. (2010). Comportamiento Frente Al Fuego De Tableros Y Madera De Pino Radiata Con Y Sin Pintura Retardante De Llama. Maderas. Ciencia Y Tecnología, 12(1), 11-24. https://doi.org/10.4067/S0718-221X2010000100002 
Garay, R. M., Figueroa, W., Pfenniger, F., Tapia, R. \& Larenas, J. (2017). Project shelter, Part 1: Fire resistance and thermal insulation. Revista de La Construcción. https://doi.org/10.7764/RDLC.16.2.339

Garay, R. M., Poblete, H., \& Karsulovic, J. T. (2009). Evaluation of oriented strandboard and plywood subjected to severe relative humidity and temperature conditions. Forest Products Journal, 59(3), 84-90.

Garay, R., \& Silva, S. (2011). Comportamiento de tableros a base de madera, durante ensayos de atenuación ultrasónica. Revista de la Construcción 10(3), 41-51. https://doi.org/10.4067/S0718-915X2011000300005

Instituto Nacional de Normalización. (2002). NCh2785. Acústica. Medición de aislación acústica en construcciones y elementos de construcción. http://www.registrocdt.cl/registrocdt/uploads/00\%20Referencias\%20Guia\%20Terminaciones/2.2.2\%20Aislacion\%20acustica/2.2.2\%20Aislaci on\%20Acustica\%20DR.pdf

Instituto Nacional de Normalización. (2000). NCh 352/1.0f2000: Aislación acústica - Parte 1: Construcciones de uso habitacional - Requisitos mínimos y ensayos, 17. http://www.contadorycampos.cl/default/upload/320120131122857.pdf

Instituto Nacional de Normalización. (2003). NCh 2786. 2003.Acústica Medición de la ais/ación acústica en construcciones. Medición en laboratorio de la aislación acústica aérea de elementos de construcción. pdf. http://biblioteca.cchc.cl/index.asp?param=0\%AD\%88\%92bh\%99\%8Cr\%5D\&Op=3

Instituto Nacional de Normalización. (2016). NCh 3393-2015. Paneles estructurales aislantes - Requisitos de fabricación, 1-24. http://www.inn.cl/paneles-estructurales-aislantes-requisitos-de-fabricacion

Insttituto Nacional de Normalización. (2010a). NCh432-2010 Cargas de https://www.academia.edu/9254838/Norma_de_Viento_NCh_432_Of._2010

Insttituto Nacional de Normalización. (2010b). NCh 431-2010. Diseño Estructural Cargas de Nieve. https://www.google.com/url?sa=t\&rct=j\&q=\&esrc=s\&source=web\&cd=3\&ved=2ahUKEwjnlOawM7hAhWMJrkGHXauBoUQFjACegQIAhAC\&url=https\%3A\%2F\%2Fwww.ucursos.cl\%2Fingenieria\%2F2005\%2F1\%2FCl62A\%2F2\%2Fmaterial_docente\%2Fbajar\%3Fid_material\%3D54489\&usg=AOvVaw06DsMFeY_QIkq OIfMyEDsL

Ministerio de la Vivienda y Urbanismo. (2006). Manual de aplicacion reglamentacion acustica. https://www.google.com/search?client=safari\&rls=en\&q=Ministerio+de+la+Vivienda+y+Urbanismo.+(2006).+Manual+de+aplicacion+reglame ntacion+acustica.\&ie=UTF-8\&oe=UTF-8

Ministerio de la Vivienda y Urbanismo. (2017). Resumen de modificaciones y rectificaciones de la ordenanza general de urbanismo y construcciones. https://www.google.com/search?client=safari\&rls=en\&q=Ministerio+de+la+Vivienda+y+Urbanismo.+(2017).+Resumen+de+modificaciones+y+ rectificaciones+de+la+ordenanza+general+de+urbanismo+y+construcciones\&ie=UTF-8\&oe=UTF-8

Ministerio de Vivienda y Urbanismo. (2013). Reglamento de la Ley N²0.703, que crea y regula el Registro Nacional de Inspectores Técnicos de Obra (ITO).

https://www.google.com/search?client=safari\&rls=en\&q=Ministerio+de+Vivienda+y+Urbanismo.+(2013).+Reglamento+de+la+Ley+N\%C2\%B0 +20.703,+que+crea+y+regula+el+Registro+Nacional+de+Inspectores+T\%C3\%A9cnicos+de+Obra+(ITO).\&ie=UTF-8\&oe=UTF-8

Ministerio de Vivienda y Urbanismo. (2014). Res_1434 2014 Aprueba Incorporación y Modificación de Soluciones para acondicionamiento térmico, acústico y Comportamiento al fuego de elementos y componentes de la construcción.

Ministerio del Medio Ambiente. (2012). Decreto 38. https://www.leychile.cl/Navegar?idNorma=1040928

Peraza, F. 2002. Comportamiento acústico, Estudio para Elementos de Carpintería de Madera. Asociación de Investigación de las Industrias de la Madera, AITIM. Madrid, España. Revista no 219. 52-54. http://infomadera.net/uploads/articulos/archivo_4504_13602.pdf

Saleh Pascha, K. (2013). Construcciones de madera compuestas para cerramientos autoportantes. ARQ (Santiago), (84), 76-83. https://doi.org/10.4067/S0717-69962013000200014

Volcan. (n.d.). Volcanita ST plancha de yeso-cartón / Estándar para soluciones constructivas de cielos rasos y tabiques. Fácil. https://www.volcan.cl/productos/volcanitas-tradicionales/volcanita-st

Zulkifli, R., M.J.Mohd, N., Tahir, M. F. M., Ismail, A., \& Nuawi, M. Z. (2008). Acoustic Properties of Multi-layer Coir Fibres Sound Absorption Panel. Journal of Aplied Sciences, 8(20), 3709-3714. 